\title{
Evaluating the Efficiency of Microbes in Mung Bean by different Tests for Improving Crop Yields
}

\author{
N. Gowri Priya*, S. Triveni, R. Subhash Reddy, K. Kranthi Kumar and K. Manasa \\ Department of Agricultural Microbiology and Bioenergy, College of Agriculture, Professor \\ Jayashankar Telangana State Agricultural University, Rajendranagar, Hyderabad-500030, \\ Telangana, India \\ *Corresponding author
}

\section{A B S T R A C T}

A major focus in the coming decades would be on safe and eco-friendly

Keywords

PSB, Enzymes, Biosolubilization, Rhizosphere

Article Info

Accepted:

26 June 2017

Available Online:

10 July 2017 methods by exploiting the beneficial micro-organisms for sustainable crop production. As mung bean is the major pulse crop in Telangana state, it was taken as a test crop in this study. A substantial number of microorganism species, mostly those associated with the plant rhizosphere have been isolated and characterized morphological, biochemical level and PGPR activities for their efficiency, rock phosphate biosolubilization, germination test, compatability studies, biofilm formation and enzyme synthesis(at different crop growth stages), for the organisms Bacillus, Pseudomonas, Rhizobium and Trichoderma viridae. For these above tests the organisms were highly responsive and more persistent and their by improved the yields.

\section{Introduction}

The rhizosphere is a narrow region of soil around the root that is directly influenced by root secretions and associated microbial activity. Bacteria that colonize the rhizosphere and plant roots, and enhance plant growth by any mechanism are referred as Plant Growth-Promoting Rhizobacteria (PGPR).

Isolation, identification and characterization of PSB (Phosphate solubilizing bacteria) isolated from economically important crop plants is more useful and the population level of PSB was higher in the rhizosphere soils
(Tensingh et al., 2015). Most efficient bacterial isolates were screened on the basis of their best performance of biochemical and PGPR activities. The above screened best phosphate solubilizing bacteria were selected for biofilm formation.

A biofilm is an aggregate of microorganisms in which cells are struck to each other and/or to a surface. In vitro screening of biofilms was carried out by different PGPR activities (Triveni et al., 2015). The capacity of solubilization of rock phosphate by different combination of biofilms was carried out 
(Gaur, 1990). And the population counts at different intervals of crop growth studies were carried out.

The nitrogen fixing ability was tested for the better nitrogen fixation in the cop root zone (Shrivastava, 2013).

These microorganisms occur in soils naturally, but their populations are often scanty.

In order to increase the crop yield, the desired microbes from rhizosphere are isolated and artificially cultured in adequate count and again introduced at root zone will improve the crop performance.

This plant-microbe interactions in the rhizosphere are responsible for increasing plant health and soil fertility (Khan, 2006).

\section{Materials and Methods}

Isolation and characterization of PSB: Soil samples were collected from the Mungbean rhizosphere soils in NBPGR, Rajendranagar, Hyderabad (Vlassak et al., 1992).

$0.1 \mathrm{ml}$ of respective samples were spread on sterilized petri plates containing specific media media i.e., Bacillus on nutrient agar, Pseudomonas on Kings B, Rhizobium on Yeast extract mannitol agar with congo red and Trichoderma on Potato dextrose agar.

The petri plates were incubated at room temperatures $\left(28^{\circ} \mathrm{C} \pm 2^{\circ} \mathrm{C}\right)$ for $24-72 \mathrm{~h}$.

\section{Morphological characterization}

All the eleven bacterial isolates cell morphology (shape, size, elevation, surface, margin, color, odour, pigmentation etc.,) and gram reaction (gram positive, gram negative) were recorded (Barthalomew and Mittewar, 1950) by using respective tests.

\section{Biochemical and characterization \\ physiological \\ Yeast Extract Mannitol Agar with Congo red test (YEMAC)}

The isolates were streaked on YEMAC media plates and incubated at $28 \pm 22^{\circ} \mathrm{C}$ for $48-72 \mathrm{~h}$. Rhizobial colonies do not absorb color and remain white in color.

\section{Hoffer's alkaline agar test}

The isolates were streaked on Hoffer's alkaline media plates and incubated at $28 \pm$ $2^{\circ} \mathrm{C}$ for 48 - $72 \mathrm{~h}$. Rhizobium does not grow on the media plates (Vincent, 1970).

All the PGPR activities were tested for their efficiency to phosphate solubilization, siderophore production, HCN production, ammonia production etc.

\section{Nitrogen fixation efficiency by Acetylene Reduction Assay (ARA)}

The roots along with nodules were placed in a $100 \mathrm{ml}$ conical flask. The flask was sealed with rubber septum (serum cap).

Ten percent $(\mathrm{v} / \mathrm{v})$ of the inert gas was removed from the flask with an air tight syringe. $10 \mathrm{ml}$ of acetylene was injected into the flask and incubated for $24 \mathrm{~h}$ at room temperature. $1 \mathrm{ml}$ gas mixture was removed from the flask with an airtight syringe. After incubation, $1 \mathrm{ml}$ of gas sample was withdrawn and injected into the gas chromatograph (Agilent $7820 \mathrm{~A}$, India) fitted with Porapak R column and Flame ionization detector (FID). The column temperature was maintained at $60{ }^{\circ} \mathrm{C}$. Nitrogen gas was used as carrier gas at the flow rate of $30 \mathrm{ml} \mathrm{min}^{-1}$ ). The acetylene and ethylene peaks were observed and ethylene peak height was measured (Bergersen, 1980). 
The acetylene reduction activity of the isolates was calculated using the formula:

Sample peak length of ethylene (mm) $\mathrm{x}$ Attenuation $\mathrm{x}$ Volume of gas phase of flask $\mathrm{x}$ 0.0006

Incubation time (h) x Volume of gas sample injected into gas chromatograph (ml)

\section{Compatability studies}

To facilitate correct compatability between the bacteria and fungi attempts were carried out for biofilm formation. The isolates were selected and their compatibility with Trichoderma was investigated in vitro using the method Perpendicular streak assay. The best showed isolates were selected and streaked on 4 sides of Trichoderma inoculated in the centre of the plates. Then further studies were carried out for their best performance (Triveni et al., 2012).

\section{Biofilm formation}

The screened best phosphate solubilizing bacteria were selected for biofilm formation. A biofilm is an aggregate of microorganisms in which cells are struck to each other and/or to a surface. The inocula used for the preparation of different biofilms were five days old culture of fungi $(3 \mathrm{ml})$ and two days old culture of bacteria $(5 \mathrm{ml})$ in $250 \mathrm{ml}$ broth. Initially $5 \mathrm{ml}$ of the bacterial culture was inoculated and then incubated for one day in a shaking incubator at $110 \mathrm{rpm}$ and then inoculation of Trichoderma viride $(5 \mathrm{ml})$. The flasks were incubated under static conditions at $30{ }^{\circ} \mathrm{C}$ for 16 days until a thick film of culture is observed on the surface of the liquid medium. The progressive growth of biofilm was observed under microscope. After 16 days of incubation the biofilm was harvested and prepared as a liquid suspension.

\section{Results and Discussion}

Bacteria exhibit a rich diversity of morphologies. Within this diversity, there is a uniformity of shape for each species that is replicated faithfully each generation, suggesting that bacterial shape is as selectable as any other biochemical adaptation.

Critical advances in studying bacterial efficiency in model bacteria like Bacillus, Pseudomonas and Rhizobium have identified and characterized by the fundamental tests responsible for increasing the efficiency. This expanding body of work revealed that Bacillus as rod shape stumpy Gram positive, Pseudomonas as small yellowish green Gram negative and small mucoid Gram negative in case of Rhizobium.

The identification of microorganisms including bacterial responses is essential for the advances in microbiology (for development of biofilms). During present experiment, a series of tests were conducted to identify bacterial responses. Upon compiling the data obtained from above analysis of bacteria, the results were generated as isolates showed a negative growth on Hofer"s Alkaline medium because Rhizobium will not grow on Hoffer's alkaline medium, this is considered as useful means to distinguish between the two allied genera (Hofer 1935). Similarly all the nine isolates did not produce yellow coloration around their colonies indicating that Agrobacterium was absent and the isolate was identified as Rhizobium. Similarly isolate did not produce yellow coloration around their colonies indicating that Agrobacterium was absent and all of them were Rhizobium. The Rhizobium isolate grew well on yeast extract mannitol agar slants and Congored yeast extract mannitol agar plates but didn't show chromo genesis. 
All the 5 B. subtilis individual isolates were able to form clear zone of phosphate solubilization on pikovaskaya's agar plate ranged from 11-18 mm. Among them GBC 1 of $B$. subtilis recorded the highest zone efficiency of $18 \mathrm{~mm}$ solubilization zone with $257.14 \%$ efficiency. Second best was GPS 4 with $171.42 \%$ solubilization efficiency followed by GBC 2 (170.00\%), GPS 5 $(166.66 \%)$ and GPS 3 (163.63\%) respectively? The Rhizobium leguminosarum exhibited lowest phosphate solubilization efficiency i.e., $123.07 \%$ with $16 \mathrm{~mm}$ solubilization zone.

Table.1 Serial dilutions used for viable plate count of different microorganisms

\begin{tabular}{|l|l|l|}
\hline S. No. & Rhizobacteria & Dilutions \\
\hline 1 & Bacillus spp (5 isolates) & $10^{-3}$ to $10^{-6}$ \\
\hline 2 & Pseudomonas spp (5 isolates) & $10^{-3}$ to $10^{-6}$ \\
\hline 4 & Rhizobium spp (1 isolate) & $10^{-3}$ to $10^{-6}$ \\
\hline 5 & Trichoderma viride (1 isolate) & $10^{-3}$ to $10^{-5}$ \\
\hline
\end{tabular}

Table.2 Cultural and morphological characteristics of Bacillus, Pseudomonas and Rhizobium Isolates

\begin{tabular}{|l|l|l|}
\hline Isolates & Cultural characteristics & Morphological characteristics \\
\hline GBC1 & Irregular, creamy whitish flat colony & Gram +ve, purple, rod shaped \\
\hline GBC 2 & Dull whitish, irregular colony & Gram +ve, purple, rod shaped \\
\hline GBC 3 & Creamy white, regular, medium colony & Gram +ve, purple, rod shaped \\
\hline GBC 4 & Light cream color, flat & Gram +ve, purple, rod shaped \\
\hline GBC 5 & Big, white, irregular colony & Gram +ve, purple, rod shaped \\
\hline GPS 1 & Yellowish green, round, fluorescent & Gram-ve, rod shaped, pink \\
\hline GPS 2 & Yellowish green, irregular, glistening, pigmented & Gram-ve, rod shaped, pink \\
\hline GPS 3 & Yellow colored, medium, spreaded & Gram-ve, rod shaped, pink \\
\hline GPS 4 & Yellowish, button shape small, round & Gram-ve, rod shaped, pink \\
\hline GPS 5 & Yellowish green, regular round & Gram-ve, rod shaped, pink \\
\hline Rhizobium & Milky, mucoid, translucent, raised & Gram-ve, rod shaped, pink \\
\hline
\end{tabular}


Table.3 Study the phosphate solubilization efficiency of different bacterial isolates

\begin{tabular}{|l|l|l|l|l|}
\hline \multirow{2}{*}{ Sl.No. } & \multirow{2}{*}{} & Isolates & \multicolumn{2}{|c|}{ Zhosphate solubilization } \\
\cline { 3 - 4 } & & $\begin{array}{l}|c| \\
\text { Solubulization } \\
\text { zone (mm) }\end{array}$ & $\begin{array}{l}\text { Culture diameter } \\
\text { (mm) }\end{array}$ & \\
\hline 1 & GBC 1 & 18.00 & 7.00 & 257.14 \\
\hline 2 & GBC2 & 17.00 & 10.00 & 170.00 \\
\hline 3 & GBC 3 & 15.00 & 12.00 & 125.00 \\
\hline 4 & GBC 4 & 14.00 & 9.00 & 155.55 \\
\hline 5 & GBC 5 & 11.00 & 8.00 & 137.50 \\
\hline 6 & GPS 1 & 0.00 & 7.00 & 0.00 \\
\hline 7 & GPS 2 & - & 8.00 & - \\
\hline 8 & GPS 3 & 18.00 & 11.00 & 163.63 \\
\hline 9 & GPS 4 & 12.00 & 7.00 & 171.42 \\
\hline 10 & GPS 5 & 15.00 & 9.00 & 166.66 \\
\hline 11 & RHIZO & 16.00 & 13.00 & 123.07 \\
\hline
\end{tabular}

Treatments: Bacillus strains (GBC 1, GBC 2, GBC 3, GBC 4, GBC 5), Pseudomonas strains (GPS 1, GPS 2, GPS 3, GPS 4, GPS 5), Rhizobium strain

Table.4 Influence of different biofilms and co-inoculations on nodule number and in nitrogenase activity

\begin{tabular}{|c|c|c|}
\hline Treatments & \begin{tabular}{|l|l|} 
Mmol of \\
Ethylene
\end{tabular} & Nodule no. \\
\hline Control & 53.33 & 7.00 \\
\hline $\mathrm{T} 1$ : Trichoderma viride + Bacillus subtilis (Biofilm) & 70.34 & 9.00 \\
\hline T2 : Trichoderma viride + Pseudomonas fluorescence (Biofilm) & 129.07 & 8.00 \\
\hline T3 : Trichoderma viride + Rhizobium leguminosarum (Biofilm) & 211.13 & 10.00 \\
\hline $\begin{array}{l}\text { T4 : Trichoderma viride }+ \text { Bacillus subtilis }+P . \text { fluorescence }+R . \\
\text { leguminosarum }(\text { Biofilm) }\end{array}$ & 219.07 & 11.00 \\
\hline $\begin{array}{l}\text { T5 : Trichoderma viride }+ \text { Bacillus subtilis } \\
\text { (Co-inoculation) }\end{array}$ & 115.20 & 9.00 \\
\hline T6 : Trichoderma viride + Pseudomonas fluorescence (Co-inoculation) & 152.30 & 8.00 \\
\hline T7 : Trichoderma viride + Rhizobium leguminosarum (Co-inoculation) & 149.10 & 9.00 \\
\hline $\begin{array}{l}\text { T8 : Trichoderma viride }+ \text { Bacillus subtilis }+ \text { Pseudomonas fluorescence }+ \\
\text { Rhizobium leguminosarum (Co-inoculation) }\end{array}$ & 131.10 & 7.00 \\
\hline CD & 0.42 & 0.99 \\
\hline $\mathrm{SE}(\mathrm{m})$ & 0.14 & 0.33 \\
\hline $\mathrm{CV}$ & 0.18 & 6.90 \\
\hline
\end{tabular}


Fig.1 Bacterial biofilm SEM imagas

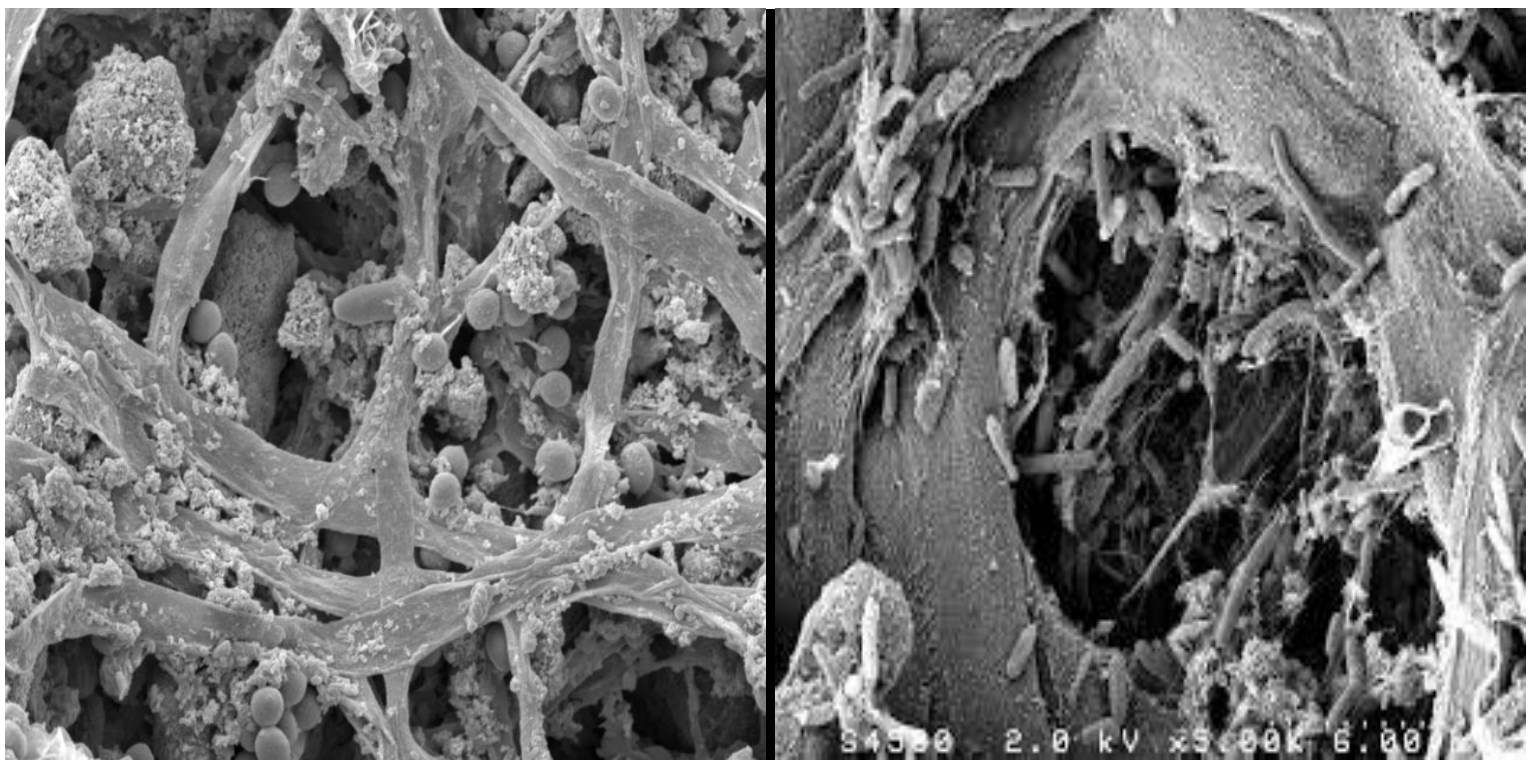

Fig.2 Microscopic image of in vitro developed Biofilms

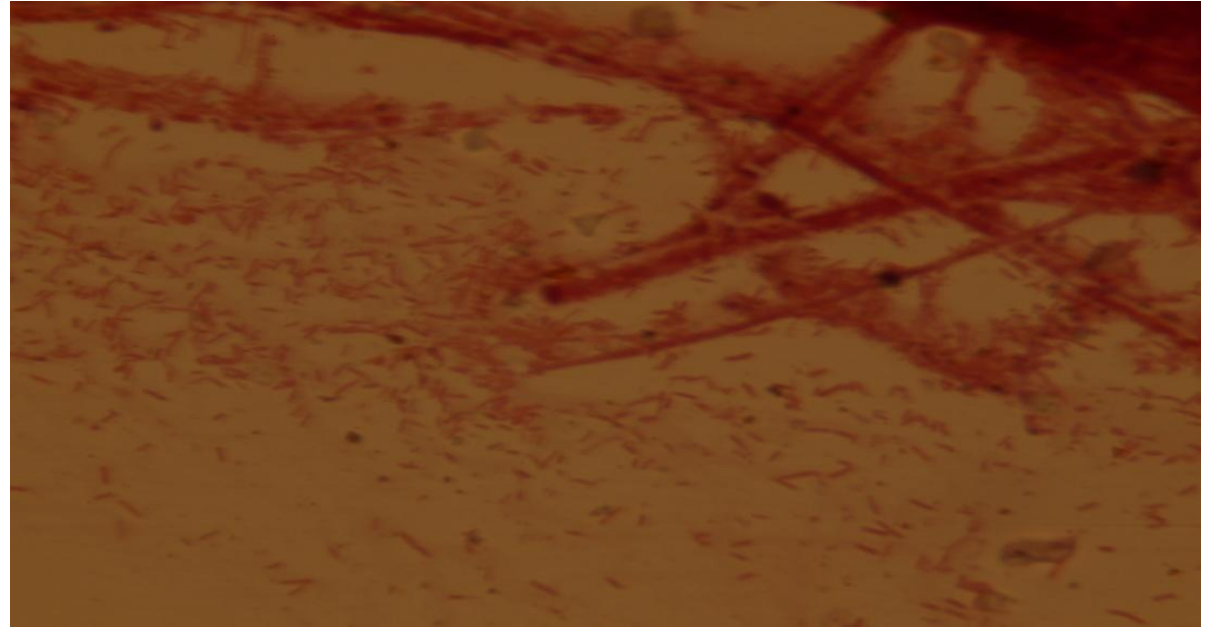

Fig.3 Compatibility studies
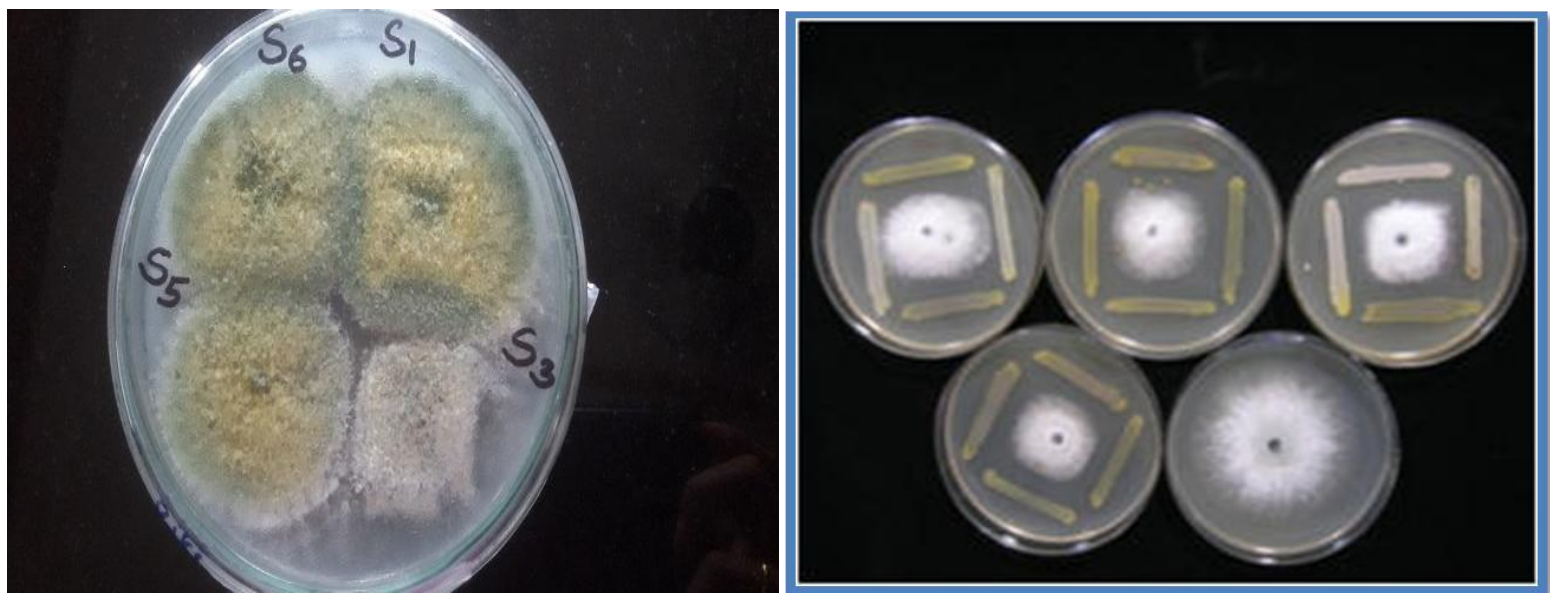
The high level of $\mathrm{C}_{2} \mathrm{H}_{4}$ produced by the plants might adversely affect plant growth and $\mathrm{N}$ fixation. ARA test provides an extremely simple and apparently accurate assay of $\mathrm{N}$ fixing activity when applied to pot-grown plants. In our study all the treatments have shown positive results. T4 (Trichoderma viride + Bacillus subtilis + Pseudomonas fluorescence + Rhizobium leguminosarum Biofilm) showed highest nitrogen fixing ability $\left(219.00 \mu\right.$ moles $\left.\mathrm{C}_{2} \mathrm{H}_{4}\right)$ followed by $\mathrm{T} 3$ (Rhizobium leguminosarum + Trichoderma viride - Biofilm) (211.00 $\mu$ moles $\left.\mathrm{C}_{2} \mathrm{H}_{4}\right)$, and least was observed in $\mathrm{T} 1$ (Trichoderma viride + Bacillus subtilis) (70.34 $\mu$ moles $\left.\mathrm{C}_{2} \mathrm{H}_{4}\right)$.

All the bacterial isolates were tested for their compatability with the fungus Trichoderma viridae for the development of novel biofilmed biofertilizers. The degree of inhibition of bacterial isolates by the fungi (Trichoderma) was very less and the feasibility of combining Trichoderma with bacterial isolates and the degree of intimacy between the two partners is very impressive. This compatability was observed effectively at different days.

Successfully the in vitro biofilm mats were developed with different microbial consortium. They were depicted as different treatments based on the microorganisms present in that particular biofilm. This in vitro developed biofilms were observed under Scanning Electron Microscope (SEM) for the better developed partnership. Then the 16 days old biofilm suspension were used for the seed treatment (Tables 14; ).

On the basis of results obtained from the experiments of in-vitro finally concluded as the better ability of these isolates and biofilms was due to its higher nitrogen fixing ability, PGPR activity, strongest interaction between bacteria and fungi (High compatablity), and resistant to different environmental conditions will influence the crop yields.

\section{References}

Barthalomew, J.W and Mittewer, T. 1950. A simplified bacterial strain. Stain Technology. 25: 153.

Bergerson, F.J. 1980. Methods for evaluating biological nitrogen fixation. John wiley and sons, New York. 702.

Gaur, A.C. 1990. Phosphate solubilizing microorganisms as biofertilizer. New Delhi: Omega Scientific Publishers.

Hofer AW (1935) Method for distinguishing between legume bacteria and their most common contaminant. J Amer Soc Agron. 27:228-30.

Khan, M.S. 2006. Screening of free-living rhizospheric bacteria for their multiple plant growth promoting activities. 163: 173-181.

Shrivastava, U.P. 2013. Isolation and initial characterization of diazotrophic Plant Growth Promoting Rhizobacteria (PGPR) from rice rhizosphere of Parsa and Bara district of Nepal. International Journal of Pharmacy \& Life Sciences. 4 (3): 24812488.

Tensingh Baliah, $\mathrm{N}$ and Jemeema Begum, $\mathrm{P}$. 2015. Isolation, identification and characterization of phosphate solubilizing bacteria (PSB) isolated from economically important crop plants. International Journal of Current Microbiology and Applied Science, 4 (3): 915-924.

Triveni, S., Radha Prasanna., Arun Kumar., Ngangom Bidyarani., Rajendra Singh and Kumar Saxena. 2015. Evaluating the promise of Trichoderma and Anabaena based biofilmsas multifunctional agents in Macrophomina phaseolina-infected cotton crop. Biocontrol Science and Technology. 25 (6): 656-670.

Triveni, S., Radha Prasanna., Livleen Shukla and Anil Kumar Saxena. 2012. Evaluating the biochemical traits of novel Trichoderma-based biofilms for use as plant growth promoting inoculants. Annals of Microbiology. DOI 10.1007/s13213-012-0573-x. 
Vincent, J.M. 1970. A manual for the practical study of the root nodule bacteria. Blackwell Scientific publications. Oxford and Edinburgh. 1-3.
Vlassak, K.L., Van, H and Duchateau, L. 1992. Isolation and characterization of fluorescent Pseudomonas associated with the roots of rice and banana grown in Sri Lanka. Plant and soil. 145: 51-63.

\section{How to cite this article:}

Gowri Priya, N., S. Triveni, R. Subhash Reddy, K. Kranthi Kumar and Manasa, K. 2017. Evaluating the Efficiency of Microbes in Mung Bean by different Tests for Improving Crop Yields. Int.J.Curr.Microbiol.App.Sci. 6(7): 2466-2473.

doi: https://doi.org/10.20546/ijcmas.2017.607.350 